УДК 553.3/4:553.2:550.4

\title{
СИЕНИТЫ И МОНЦОНИТЫ СИЯ-УШПИНСКОГО МЕЖДУРЕЧЬЯ ГОРНОГО АЛТАЯ: АБСОЛЮТНЫЙ ВОЗРАСТ, ГЕОХИМИЯ И ПЕТРОЛОГИЯ
}

\author{
Гусев Анатолий Иванович1, \\ anzerg@mail.ru
}

\section{Табакаева Евгения Михайловна²,} tabakaevaem@mail.ru

1 Алтайский государственный гуманитарно-педагогический университет им. В.М. Шукшина, Россия, 659333, г. Бийск, ул. Владимира Короленко, 53.

2 Алтайский государственный университет,

Россия, 656049, г. Барнаул, пр. Ленина, 61.

\begin{abstract}
Актуальность выполненных исследований связана с необходимостью уточнения абсолютного возраста и изучения особенностей петрологии и геохимии умеренно-щелочных пород - сиенитов и монцонитов Сия-Ушпинского междуречья на северовостоке Горного Алтая в России для определения закономерностей фоомирования, связанного с ними золотого оруденения. Проблема генезиса щелочных изверженных пород продолжает привлекать внимание ученых многих стран в связи с тем, что эти породы используются для подтверждения мантийно-корового взаимодействия и определения характера эволюции континентальной коры. Сегодня ещё нет единой позиции на их происхождение.

Цель: определить абсолютный возраст щелочных сиенитов Ульменского рудного поля, изучить петрологические и геохимические особенности сиенитоидов и монцонитов Сия-Ушпинского междуречья с использованием комплекса петрологических диаграмм, позволяющих выявлять физико-химические особенности петрогенезиса.

Главными объектами изучения были сиенитоиды и монцониты ульменского пироксенит-сиенит-монцонит-габбрового комплекса среднего кембрия, расположенные в Сия-Ушпинском междуречье. Данная территория приурочена к аномальному тектоническому блоку, сформировавшемуся на стыке горно-алтайских, горно-шорских и салаирских структур. Среди минералов объектами исследования являются цирконы из щелочных сиенитов Западного участка Ульменского рудного поля.

Meтоды. Oпределение абсолютного возраста пород выполнено U-Pb методом с помощью ионного микрозонда SHRIMP-II по циркону в Лаборатории ВСЕГЕИ (2. Санкт-Петербург). Геохимические данные интерпретировались с помощью комплекса петрологических диаграмм. Тетрад-эфффект фрракционирования РЗЭ (TE1,3) рассчитан по методике В. Ирбер.

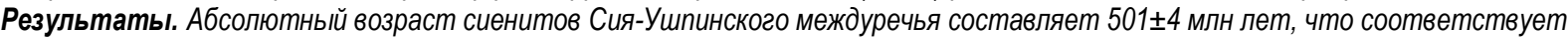
кониу среднего кембрия. Получены данные о вещественном составе сиенитов и монцонитов района Большого Личима, Ушпы, Ульмени, Верхнего Каракана, Салазана в пределах Сия-Ушпинского междуречья. Установлена последовательность их образования с выделением трех фраз: 1 фаза - монцониты, 2 фаза - щелочные сиениты, 3 фаза - сиениты. Монцониты и сиениты относятся к породам среднего состава умереннощелочной серии. Помимо этого, состав изученных нами монцонитов и сиенитов соответствует шошонитовой серии. Высокие отношения Nb/Ta (от 19,0 до 31,4) и Zr/Hf (om 30,4 до 60,6) в сиенитоидах и монцонитах Сия-Уипинского междуречья свидетельствуют о вовлечении в плавление материала нижней коры. Относительно низкие концентрации $\mathrm{Ni}$ (om 2,3 до 4,1 2/m), Cr (om 1,0 до 3,2 2/m) и MgO (от 0,27 до 1,39 \%) в сиенитах и монцонитах указывают на то, что они не могли быть продуктом прямого плавления мантийной магмы и результатом фрракционирования маффических минералов из эволюционированного расплава. Следовательно, генерация сиенитов и монионитов СияУипинского междуречья происходила по сценарию, в котором основная роль отводится расплавам, сформированным в результате частичного плавления материала нижней утолщённой коры. На экспериментальных диаграммах, позволяющих реставрировать источник плавления для магматических пород, составы сиенитоидов и монцонитов Сия-Уипинского междуречья попадают или близко тяготеют к полям плавления амфиболитов и граувакк. В изучаемых породах выявлен тетрадэфффект M-типа в спектре распределения редкоземельных элементов, что указывает на их насыщение фрлюидами, среди которых важная роль принадлежала $\mathrm{CO}_{2}$ и $\mathrm{H}_{2} \mathrm{O}$. Последние имели ключевое значение для перемещения и концентрации золота. Авторская диаграмма $A u$ - TE1,3 показывает тренд повышения содержания золота при возрастании значений тетрадэффекта M-типа в спектре распределения редкоземельных элементов. Пространственно с областью распространения сиенитов и монцонитов связаны многочисленные проявления золота, золотоносные россыпи, а также Ульменское золотомедно-скарновое месторождение. На последнем наиболее богатое оруденение тяготеет к дайкам сиенитов.
\end{abstract}

\section{Ключевые слова:}

Умеренно-щелочный магматизм, сиениты, монцониты, петрология, циркон, тетрад-эфффект фрракционирования редкоземельных элементов, золото, Горный Алтай.

\section{Введение}

Ненасыщенные кремнием плутонические комплексы являются одной из загадочных групп умеренно-щелочных пород. Происхождение калиевого магматизма обсуждается уже многие годы [1-5]. Его продукты встречаются в различных геодинамических обстановках. Главным образом щелочные изверженные породы тяготеют к тектоническим обстановкам растяжения, таким как пост-орогенные, или внутриплитные [6-8], плюмовые обстановки крупных изверженных провинций $[9,10]$, а также к районам субдукции $[11,12]$. Пространственный анализ ГИС на основе глобальной геохимической базы данных GEOROC также подтверждает приуроченность кайнозойских щелочных пород к границам плит или к горячим точкам, связанным с мантией и плюмом [13]. Значимость 
изучения продуктов калиевого магматизма определяется тем, что они используются для подтверждения мантийно-корового взаимодействия и характера эволюции континентальной коры [14-16].

Предложено несколько моделей происхождения щелочных пород и характера магматических процессов, которые включают: 1 - остаточные расплавы, образованные в результате фракционной кристаллизации щелочных базальтовых магм [16, 17]; 2 - расплавы, сформированные низкой степенью частичного плавления метасоматизированной мантии [5, 11,14 , 18-21]; 3 - расплавы, образовавшиеся благодаря частичному плавлению коровых материалов в условиях давлений, типичных для основания утолщённой земной коры в закрытой системе [22, 23], или в связи с притоком летучих компонентов $[15,24] ; 4$ - смесь коровой анатектической гранитной и мантийнопроизводной мафической магм, сопровождающаяся последующей кристалл-дифференциацией $[1,3,25]$. Однако согласие в объяснении процессов становления и генезиса калиевых магм так и не достигнуто [4, 26-28].

Как правило, сиениты и монцониты формируются в несколько стадий, образуя сложные комплексы и серии пород. Так, на территории Центральной Камчатки сформировалась калиевая вулканоплутоническая серия пород, которая варьируется от монцогаббро- и монцодиорита до монцонита и сиенит-порфира, за которой следует второй магматический цикл трахитовых сиенит-порфиров и, возможно, других более дифференцированных монцонитовых фаз [20].

По особенностям химического состава сиенитоиды близки к шошонитовой серии [20]. Более высокое содержание K, LILE и несовместимых элементов в шошонитовых магмах по сравнению с известковощелочными обусловлено более низкой степенью плавления [12]. Для высококалиевых магматических пород, переходных к шошонитам, характерны высокие средние значения $\mathrm{K}_{2} \mathrm{O} / \mathrm{Na}_{2} \mathrm{O}$ и высокие средние отношения $\mathrm{Ce} / \mathrm{Yb}[19]$.

Металлогенический профиль сиенитоидов преимущественно золоторудный. Пространственно и парагенетически с сиенитами связано золото-сульфиднокварцевое, золото-джаспероидное оруденение в Юхтино-Пуриканской рудной зоне Якутии (месторождения Самолазовское, Гарбузовское, Томмотское и проявление Аномальное) [29]. Кроме того, со щелочными комплексами связаны порфировые $\mathrm{Cu}-\mathrm{Au}$ системыместорождения Рябиновое (Алдан) [30], Кирганикское (Камчатка) [20, 30], крупнейшее месторождение меди Юлонг (Китай) [31] и многие другие золоторудные объекты, а также эпитермальное золотое оруденение. Примером последнего является месторождение Ладолам на острове Лихир (Папуа-Новая Гвинея) - одно из крупнейших эпитермальных месторождений золота, обнаруженных в настоящее время [19].

Отмечается важная роль летучих компонентов в контроле золотого оруденения. Так, в районе месторождения Ладолам установлено особенно высокое содержание хлора в слюдах (флогопите и биотите) до 0,15 мас. \%, а также высокое значение летучести кислорода $\left(\mathrm{fO}_{2}\right)$ в щелочных породах. Предполагается, что комплексообразование хлоридов в значительной степени контролировало содержание $\mathrm{Au}$ и $\mathrm{Cu}$ в водных флюидах, ответственных за гидротермальную минерализацию золота в Ладоламе [19]. На основе результатов исследований крупнейшего в Китае месторождения золота Дунпин, связанного с интрузиями сиенитов, предлагается использование цирконов в качестве индикаторов источников флюидов и рудогенеза в многоступенчатой гидротермальной системе [32]. Месторождение Дунпин расположено на северной окраине Северо-Китайского кратона и сформировалось в результате двух этапов минерализации среднедевонской ( 380 млн лет) и раннемеловой ( 140 млн лет). Девонские гидротермальные цирконы, извлеченные из золотоносных кварцевых жил, образовались в результате метасоматических изменений магматических цирконов под действием богатого фтором флюида, что позволяет предполагать его магматическую природу, наряду с автометасоматическими процессами при кристаллизации сиенитов Шуйцюаньгоу, тогда как на меловом этапе золотой минерализации вовлекался флюид, выделившийся из щелочного плутона Шаншуйцюань. Золотая минерализация первой стадии характеризуется высоким содержанием золота $(>10$ г/т), для второй стадии свойственны более низкие содержания золота $(<10$ г/т) [33].

В Горном Алтае сиениты и монцониты, с которыми связаны грейзеновые проявления олова, встречаются в составе Бабырганского и Айского массивов одноименного комплекса раннего триаса, а также в еландинском монцодиорит-габбровом комплексе среднего кембрия [34]. В Салаире монцониты и сиениты, с которыми парагенетически связаны медномолибденовые проявления, присутствуют в жерновском монцонит-граносиенит-гранит-лейкогранитовом комплексе [35].

В северо-восточной части Горного Алтая на стыке горно-алтайских, горно-шорских и салаирских структур сформировался аномальный тектонический блок, в котором главные разломы, сопровождаемые тектонитами с признаками сдвигового пластического течения, имеют северо-восточную ориентировку. В этом тектоническом блоке проявлены сиенитоиды и монцониты, входящие в состав ульменского пироксенитсиенит-монцонит-габбрового комплекса среднего кембрия (рис. 1).

К области распространения сиенитов СияУшпинского междуречья пространственно тяготеют месторождения и проявления золото-медно-скарнового, 30лото-сульфидно-кварцевого геолого-промышленных типов, а также промышленные россыпи золота по рекам Ульмень, Ушпа, Салазан и Сия. По некоторым из них в настоящее время проводится добыча россыпного золота.

Для определения закономерностей формирования золотого оруденения, распространенного в СияУшпинском междуречье, необходимо изучение петрологии и геохимии умеренно-щелочных пород - сиенитов и монцонитов, а также уточнение их абсолютного возраста. 


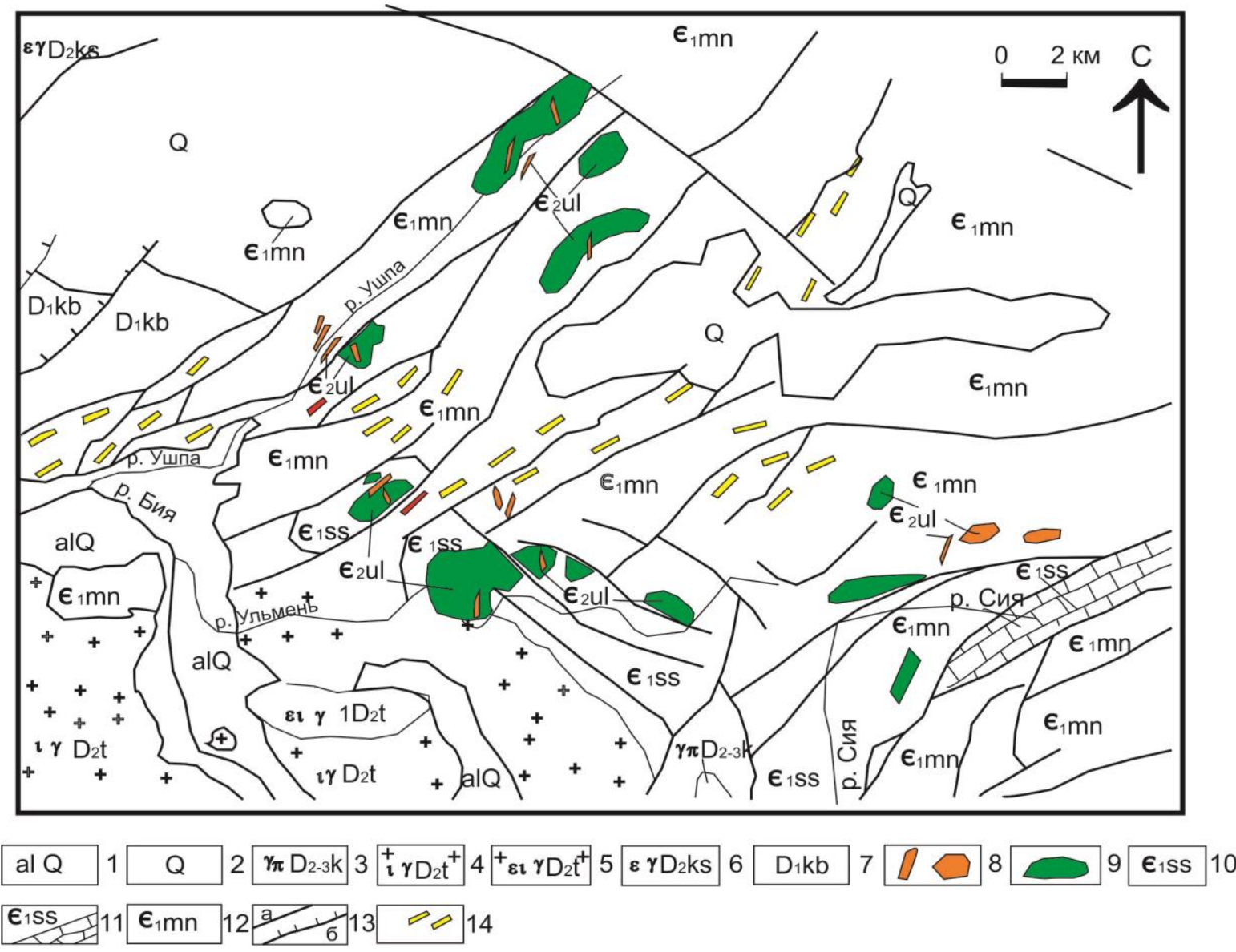

Рис. 1. Геологическое строение Сия-Ушпинского междуречья: 1 - аллювиальные образования квартера; 2 - неразделённые образования квартера; 3 - гранит-порфиры кызылташского комплекса; турочакский комплекс: 4 лейкограниты, 5 - сиено-лейкограниты; 6 - сиенограниты кистальского комплекса; 7 - пестроцветные песчаники, алевролиты, конгломераты кубойской свиты; ульменский комплекс: 8 -малье интрузии и дайки сиенитов, 9 -габбро и пироксениты; сиинская свита: 10 - песчаники и алевролиты; 11 -известняки и мраморы; 12 - алевролиты, туфы, сланцыь, базальты манжерокской свиты; 13 - разломы: а - сложной кинематики, б-надвиги; 14 - тектониты

Fig. 1. Schematic map of geological structure of Siya-Ushpinsky interfluve: 1 -alluvial deposits of quarter; 2 - undivided deposits of the quarter; 3 - granite-porphyry of the Kyzyltash complex; Turochak complex: 4 -leucogranites; 5 sieno-leucogranites; 6 - sienogranites of the Kistal complex; 7 - particolored sandstones, aleurolites, conglomerates of the Kuboy suite; Ulmen complex: 8 -dikes and small intrusions of syenites, 9 - gabbro and pyroxenites; Siya suite: 10 - aleurolites and sandstones; 11 - limestones and marbles; 12 - aleurolites, tuffs, slates, basalts of the Manzherok suite; 13 -faults: $a$-complex kinematics, $b$-thrusts; 14 -tectonites

\section{Материалы и методы исследования}

Полевое изучение взаимоотношений сиенитов и монцонитов проведено в районе Большого Личима, Ушпы, Ульмени, Верхнего Каракана, Салазана в пределах Сия-Ушпинского междуречья. Проба для определения абсолютного возраста отобрана из самостоятельного небольшого тела щелочных сиенитов Западного участка Ульменского рудного поля (рис. 2). Абсолютное датирование выполнено U-Pb методом с помощью ионного микрозонда SHRIMP-II по циркону в Лаборатории ВСЕГЕИ (г. Санкт-Петербург). Материалы исследования также составили результаты силикатных и микроэлементных анализов разных лет, выполненных методом ICP-MS для сиенитов (Большой Личим, Ульмень, Верхний Каракан, Салазан), щелочных сиенитов (Большой Личим, Ульмень), кварцевых монцонитов (Ушпа), монцонитов (Верхний Каракан).
Геохимические данные интерпретировались с помощью комплекса диаграмм - ТАС-диаграммы по [36]; $\mathrm{SiO}_{2}$ - A.R. по [37]; $\mathrm{K}_{2} \mathrm{O}$ - $\mathrm{SiO}_{2}$; диаграмм состава экспериментальных расплавов из плавления фельзических пелитов (мусковитовых сланцев), метаграувакк и амфиболитов [38]; диаграммы $\mathrm{Au}-\mathrm{TE}_{1,3}$. Тетрад-эффект фракционирования РЗЭ $\left(\mathrm{TE}_{1,3}\right)$ рассчитан по методике В. Ирбер [39]. Значения редкоземельных элементов нормированы относительно хондрита [40]. Еu* рассчитан по формуле $\left(\mathrm{Sm}_{\mathrm{N}}+\mathrm{Gd}_{\mathrm{N}}\right) / 2$.

\section{Абсолютная датировка сиенитов}

Цирконы темно-коричневого цвета, прозрачные, полупрозрачные и мутные. Представлены идиоморфными кристаллами короткопризматического облика и их обломками. Длина зерен 100-250 мкм, коэффициент удлинения от 1 до 2. В катодолюминесценции кристаллы и их обломки слабого свечения двухфаз- 
ного строения: более светлая центральная часть с элементами секториальной зональности и темная кра- евая. Все точки измерений относятся к центральным частям циркона.

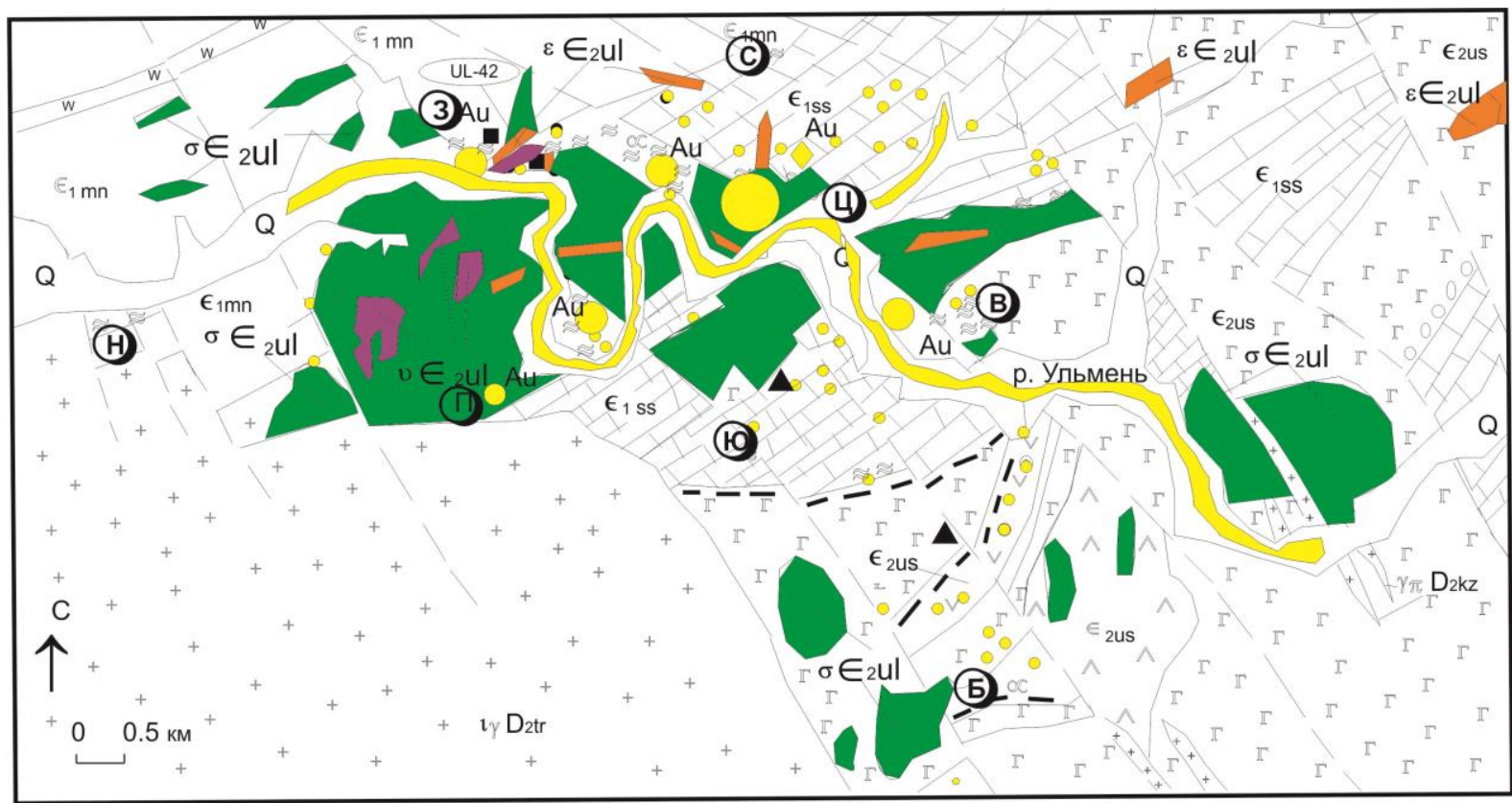

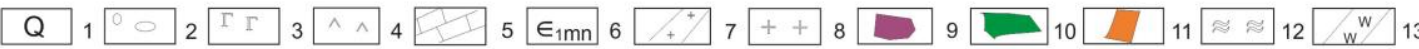

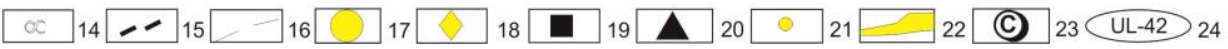

Рис. 2. Схема геологического строения и золотоносность Ульменского рудного поля (составлена А.И. Гусевым с учётом материалов Ю. Тверитинова): 1 - современные аллювиальные образования; усть-семинская свита: 2 - конгломераты; 3 - лавы, туфы базальтов и трахибазальтов; 4 - лавы и туфы андезитов, трахиандезитов; 5 - известняки и мраморы сиинской свиты; 6 - алевролиты, сланиы, туфы, базальты манжерокской свиты; 7 - гранит-порфиры кызылташского комплекса; 8 - граниты и лейкограниты турочакского комплекса; ульменский комплекс: 9 - пироксениты, габбро-пироксениты I фазы; 10 - габбро II фазы; 11 - мониониты, квариевые щелочные сиениты и сиениты III фазы; 12 - скарны; 13 - кварциты; 14 - зоны лимонитизачии; 15 - зоны рассланцевания; 16 - разломы; 17 - золото-медно-скарновые руды; 18 - золотосульфидно-квариевые проявления; 19 - «железные шляпь» и лимонитовые «сухари»; 20 - проявления магнетита; 21 - находки золота в шлихах; 22 - россыпи золота; 23 - золотоносные участки рудного поля: Ц Центральный, $B$ - Восточный, 3 - Западный, $K$ - Каменный, Ю - Южный, $C$ - Северный, П - Первый, $H$ Нижний, Б-Берёзовско-Макарьевский; 24 - место отбора пробы для определения абсолютного возраста сиенитов

Fig. 2. Schematic map of geological structure and auriferous of Ulmen ore field (created by A.I. Gusev taking into account the materials of Yu. Tveritinov): 1 - modern alluvial deposits; ust-semin suite: 2 - conglomerates; 3 -lavas, tuffs of basalts and trachybasalts; 4 - lavas and tuffs of andesites, trachyandesites; 5 - limestones and marbles of the Siya suite; 6 - siltstones, tuffs, shales, basalts of the Manzherok suite; 7 - granite-porphyry of the Kyzyltash complex; 8 granites, leucogranites of the Turochak complex; Ulmen complex: 9 - pyroxenites, gabbro-pyroxenites of the first phase; 10 - gabbro of the second phase; 11 - monzonites, quartz alkaline syenites and syenites of the third phase; 12 - skarns; 13 -quartzite; 14 - zones of limonitization; 15 -zones of foliation; 16 -faults; 17 - gold-copper-skarn ores; 18 - gold-sulfide-quartz manifestations; 19 - gossan; 20 - manifestation of magnetite; 21 - finds of gold in concentrates; 22 - placers of gold; 23 - gold-bearing areas of the ore field: $Ц$ - Central; $B$ - Eastern; 3 - Western; $K$-Rock; $O$-Southern; $C$-Northern; $\Pi$-First; $H$-Lower; 5 -Berezovsko-Makaryevsky; 24 - sampling point for syenites absolute age determination

Содержание в цирконе (ppm): $\mathrm{U}=446-8412$, $\mathrm{Th}=176-8307, \mathrm{Th} / \mathrm{U}=0,27-1,02$. По результатам $\mathrm{U}-\mathrm{Pb}$ датирования по цирконам получена дискордия с верхним пересечением $504 \pm 7$ млн лет. Из них для 8 анализов $(8.1,11.1,3.1,1.1,6.1,2.1,4.1,7.1)$ установлен конкордантный возраст $501 \pm 4$ млн лет. Изотопный состав $\mathrm{Pb}, \mathrm{U}, \mathrm{Th}$ в цирконах сиенитов и абсолютные возраста замеров приведены в таблице.

Возраст кристаллизации сиенитов среднекембрийский, близкий к границе с поздним кембрием.

\section{Петро-геохимия породных типов}

Сиенитоидная группа пород ульменского комплекса представлена монцонитами, кварцевыми монцонитами, сиенитами и псевдолейцитовыми сиенитами. Они встречаются как самостоятельные дайки и входят в состав малых интрузивных тел. При этом псевдолейцитовые сиениты в сложных телах встречаются в центральных частях совместно с монцонитами среди сиенитов в виде небольших фрагментов $2 \times 3$ м. Полевое изучение пород показало, что монцонитоиды претерпели дробление и вторичные 
изменения в приконтактовых частях. Монцониты и кварцевые монцониты в таких телах присутствуют в виде ксенолитовых образований среди сиенитов, обычно в центральных частях. Это указывает на то, что монцонитоиды образуют самую раннюю фазу внедрения, подвергшуюся дроблению после кристаллизации. Таким образом, можно выделить следующие интрузивные фазы: 1) монцониты, 2) щелочные сиениты, 3) сиениты.

Таблица. Абсолютные возраста и изотопный состав $\mathrm{Pb}, \mathrm{U}$, Тh в иирконах сиенитов Ульменского рудного поля Table. $\quad$ Absolute ages and isotopic composition of $\mathrm{Pb}, U$, Th in zircons of syenites of Ulmen ore field

\begin{tabular}{|c|c|c|c|c|c|c|c|c|c|c|}
\hline $\begin{array}{c}\text { Точки } \\
\text { замеров } \\
\text { Test points }\end{array}$ & $\begin{array}{c}{ }^{206} \mathrm{~Pb}_{\mathrm{c}} \\
\%\end{array}$ & $\begin{array}{c}\mathrm{U}, \\
\Gamma / \mathrm{T} \\
\mathrm{ppm}\end{array}$ & $\begin{array}{l}\text { Th, } \\
\Gamma / \mathrm{T} \\
\mathrm{ppm}\end{array}$ & $\frac{{ }^{232} \mathrm{Th}}{{ }^{238} \mathrm{U}}$ & $\begin{array}{c}\frac{{ }^{206} \mathrm{~Pb}}{{ }^{238} \mathrm{U}} \\
\text { Возраст, млн лет } \\
\text { Age, Ма } \\
\end{array}$ & $\begin{array}{c}\frac{{ }^{207} \mathrm{~Pb}}{{ }^{206} \mathrm{~Pb}} \\
\text { Возраст, млн лет } \\
\text { Age, Мa } \\
\end{array}$ & $\frac{{ }^{238} \mathrm{U}}{{ }^{206} \mathrm{~Pb}}$ & $\frac{{ }^{207} \mathrm{~Pb}^{*}}{{ }^{206} \mathrm{~Pb}^{*}}$ & $\frac{{ }^{207} \mathrm{~Pb}^{*}}{{ }^{006} \mathrm{~Pb}^{*}}$ & $\frac{{ }^{206} \mathrm{~Pb}^{*}}{{ }^{238} \mathrm{U}}$ \\
\hline 5.1 & 0,17 & 1426 & 560 & 0,41 & $453 \pm 8$ & $527 \pm 20$ & 13,7 & 0,0579 & 0,58 & 0,073 \\
\hline 12.1 & 0,04 & 1120 & 471 & 0,43 & $468 \pm 6$ & $516 \pm 21$ & 13,3 & 0,0576 & 0,60 & 0,075 \\
\hline 10.1 & 0,01 & 2049 & 602 & 0,3 & $475 \pm 6$ & $510 \pm 14$ & 13,1 & 0,0575 & 0,61 & 0,076 \\
\hline 8.1 & - & 1216 & 616 & 0,52 & $482 \pm 7$ & $507 \pm 19$ & 12,9 & 0,0574 & 0,61 & 0,078 \\
\hline 11.1 & 0,04 & 1361 & 355 & 0,27 & $494 \pm 4$ & $503 \pm 17$ & 12,5 & 0,0573 & 0,63 & 0,080 \\
\hline 3.1 & 0,02 & 2589 & 558 & 0,34 & $499 \pm 4$ & $506 \pm 12$ & 12,4 & 0,0574 & 0,64 & 0,080 \\
\hline 1.1 & - & 446 & 176 & 0,41 & $505 \pm 4$ & $527 \pm 30$ & 12,3 & 0,0579 & 0,65 & 0,081 \\
\hline 6.1 & 0,05 & 3249 & 2177 & 0,69 & $508 \pm 6$ & $496 \pm 11$ & 12,2 & 0,0571 & 0,65 & 0,082 \\
\hline 2.1 & 1,28 & 2283 & 1797 & 0,81 & $514 \pm 9$ & $547 \pm 47$ & 12,0 & 0,0584 & 0,67 & 0,083 \\
\hline 4.1 & 0,40 & 2413 & 2039 & 0,87 & $515 \pm 8$ & $515 \pm 17$ & 12,0 & 0,0576 & 0,66 & 0,083 \\
\hline 7.1 & 0,91 & 2969 & 1315 & 0,46 & $515 \pm 14$ & $507 \pm 22$ & 12,0 & 0,0574 & 0,66 & 0,083 \\
\hline 9.1 & 0,14 & 8412 & 5307 & 1,02 & $563 \pm 9$ & $486 \pm 8$ & 11,0 & 0,0569 & 0,72 & 0,091 \\
\hline
\end{tabular}

Пояснение. Ошибки равны 1-сигма. Р $b_{c}$-обычная часть свинца; $\mathrm{Pb}$ * - радиогенная часть свиниа. Общий Рb скорректирован с помощью измеренного изотопа ${ }^{204} \mathrm{~Pb}$.

Note. Errors are equal to 1-sigma; $P b_{c}-$ common part of lead; $\mathrm{Pb}^{*}$-radiogenic part of lead. Total Pb is corrected using measured ${ }^{204} \mathrm{~Pb}$ isotope.

Монцониты представляют собой крупнокристаллические породы серой окраски. Они более крупнокристаллические, чем сиенитоиды. Состав (\%): 30нальный кали-натровый полевой шпат (30-32), роговая обманка (f=51-59) (2-3), клинопироксен (6-8), биотит (4-5), плагиоклаз (36-41), который по составу отвечает номерам 32-46. Акцессории: магнетит, апатит, циркон, сульфиды, сфен, пренит, турмалин. В краевых частях зонального кали-натрового полевого шпата присутствуют микровключения салита, биотита, плагиоклаза. Биотит по составу соответствует сидерофиллиту. Темноцветные минералы местами замещены эпидотом и хлоритом. В кварцевых монцонитах появляется кварц (2-3\%).

Щелочные сиениты чаще всего имеют серорозовую и красновато-розоватую окраску, среднекристаллическое сложение. Микроструктура гипидиоморфнозернистая и микроклин-пертитовая. Состав (\%): озаннит - 6-10, роговая обманка обыкновенная - 4-7, эпидот - 2-3, плагиоклаз - 10-15, микроклин - 75-80. Акцессорные минералы: циркон, апатит, сфен, сульфиды, ортит, пренит - единичные зёрна. Озаннит образует овоидные выделения размерами до $1 \mathrm{~cm}$, создавая порфировидную структуру. Обыкновенная роговая обманка образует скопления мелких зёрен с отчётливым плеохроизмом от желтовато-зеленоватого до зеленовато-синего. Замещается эпидотом и хлоритом. Плагиоклаз определён олигоклазом № 10-12, местами сильно пелитизирован. Микроклин-пертит наблюдается в виде крупных изометричных выделений, нередко имеющих зональное строение. В центре их локализуется плагиоклаз (альбит), на который нарастает микроклин-пертит. Изредка отмечаются миароловые пустотки, инкрустированные по краям таблитчатыми кристалликами полевого шпата, эпидота и пренита.
Сиениты - мелкозернистые породы светло-серого с розоватым оттенком и светло-красного цвета. Имеют гипидиоморфнозернистую микроструктуру. Перечень минералов (\%): микроклин-пертит - 75-80, плагиоклаз - 7-10, роговая обманка - 5-9, кварц - 1-2, эпидот - 1-2, апатит, циркон, сфен, сульфиды - единичные зёрна. Преобладающий микроклин-пертит формирует изометричные зёрна, редко - крупные призматические выделения, имеющие зональное строение. В ядре таких кристаллов отмечается более интенсивная пелитизация. Плагиоклаз наблюдается в виде таблитчатых выделений и относится к альбитолигоклазу с № 8-18. Обыкновенная роговая обманка окрашена в зеленовато-синеватые оттенки, ксеноморфна и часто замещается эпидотом и хлоритом.

Химический состав пород ульменского комплекса отражен в работе [41].

На диаграмме ТAC по [36] сиениты и монцониты попадают в соответствующие поля (рис. 3, a). Щелочные сиениты на этой диаграмме попадают в поле фельдшпатоидных сиенитов, а на диаграмме A.R. $\mathrm{SiO}_{2}$ по [37] они локализуются в области пералкалиновых пород (рис. 3, б).

Диаграмма $\mathrm{K}_{2} \mathrm{O}-\mathrm{SiO}_{2}$ позволяет относить анализируемые породы к банакитам шошонитовой серии (рис. 4).

На спайдер-диаграмме просматриваются в целом согласованные кривые распределения редкоземельных элементов для всех типов пород. На этом фоне видны негативная европиевая аномалия, а также пониженные концентрации празеодима в некоторых пробах сиенитов (рис. 5). Отрицательная аномалия по европию во всех породных типах также подтверждается низкими отношениями $\mathrm{Eu} / \mathrm{Eu}^{*}$, варьирующими от 0,36 до 0,51 . 

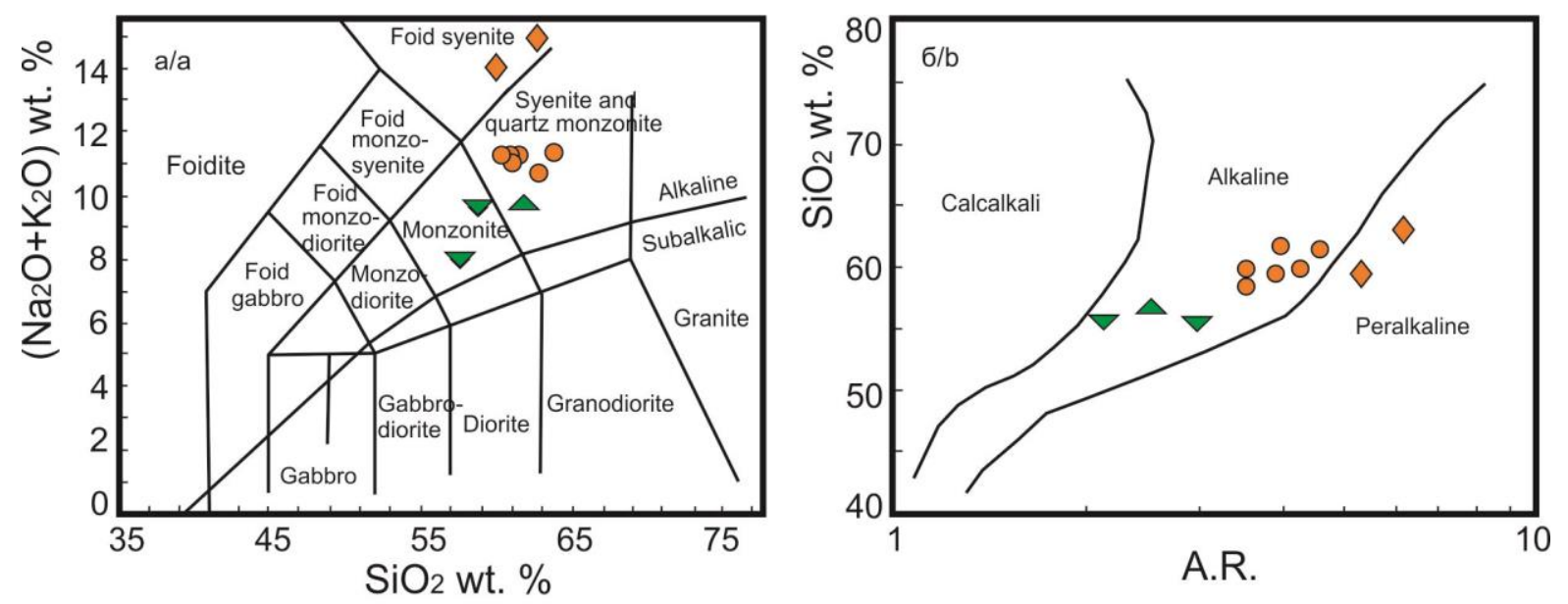

\section{$\nabla 1 \Delta 2 \bigcirc 3 \diamond 4$}

Pис. 3. Сиениты и монцониты Сия-Ушпинского междуречья на диаграммах: а) ТАС-диаграмма по [36]; б) $\mathrm{SiO}_{2}-$ A.R. по [37]. Породы: 1 - мониониты; 2 - кварцевые монцониты; 3 - сиениты; 4 - щелочные сиениты. $A . R .=\left[\mathrm{Al}_{2} \mathrm{O}_{3}+\mathrm{CaO}+\mathrm{Na}_{2} \mathrm{O}+\mathrm{K}_{2} \mathrm{O}\right] /\left[\mathrm{Al}_{2} \mathrm{O}_{3}+\mathrm{CaO}-\mathrm{Na}_{2} \mathrm{O}-\mathrm{K}_{2} \mathrm{O}\right]$

Fig. 3. Plots: a) TAS-plot [36]; b) $\mathrm{SiO}_{2}-A . R$. [37] for syenites and monzonites of the Siya-Ushpinsky interfluve. Rocks: 1 -monzonites; 2 - quartz monzonites; 3 - syenites; 4 - alkaline syenites. A.R. $=\left[\mathrm{Al}_{2} \mathrm{O}_{3}+\mathrm{CaO}+\mathrm{Na}_{2} \mathrm{O}+\mathrm{K}_{2} \mathrm{O}\right] /\left[\mathrm{Al}_{2} \mathrm{O}_{3}+\mathrm{CaO}-\mathrm{Na}_{2} \mathrm{O}-\mathrm{K}_{2} \mathrm{O}\right]$

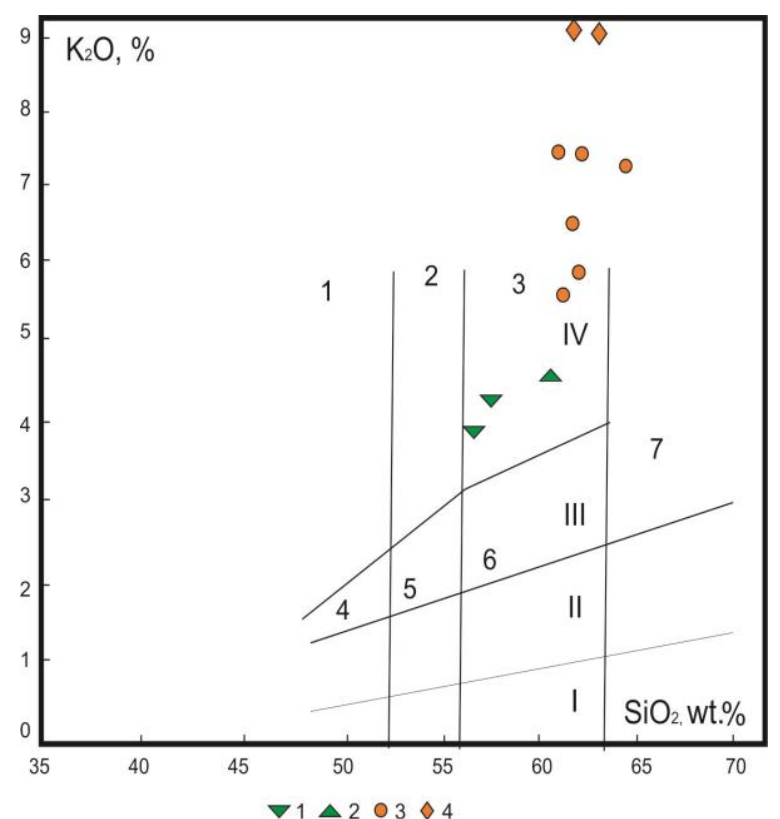

Pис. 4. Сиениты и монцонить Сия-Ушпинского междуречья на диаграмме $\mathrm{K}_{2} \mathrm{O}-\mathrm{SiO}_{2}$. Поля пород: 1 - абсарокит; 2- шошонит; 3 - банакит; 4 - высоко-калиевый базальт; 5 - высококалиевый андезибазальт; 6 - высоко-калиевый андезит; 7 - высоко-калиевый даиит по [42]. Серии пород: I - толеитовая; II - известковощелочная; III - высоко-калиевая известковощелочная; IV - шошонитовая. Условные обозначения - на рис. 3

Fig. 4. Plot $\mathrm{K}_{2} \mathrm{O}-\mathrm{SiO}_{2}$ for syenites and monzonites of the Siya-Ushpinsky interfluve. Rock fields: 1 absarokite; 2 -shoshonite; 3 - banakite; 4 - K-rich basalt; 5 - K-rich andesite basalt; 6 - K-rich andesite; $7-K$-rich dacite is presented according to [42]. Series of rocks: I-tholeiitic; II - calc-alkaline; III - K-rich calc-alkaline; 4 - shoshonite. Legend is shown in Fig. 3.

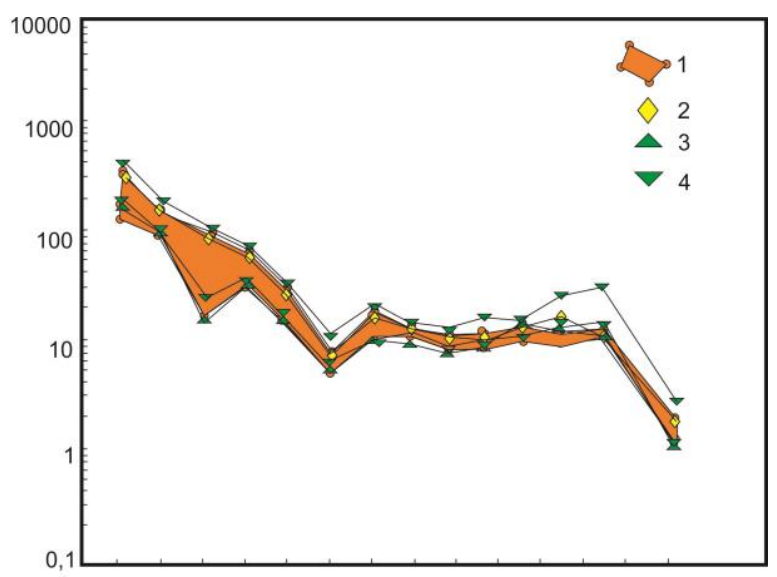

La Ce Pr Nd Sm Eu Gd Tb Dy Ho Er Tm Yb Lu

Pис. 5. Распределение РЗЭ в сиенитах и монцонитах Сия-Уипинского междуречья. Значения нормированы относительно хондрита [40]. 1 - обобщённый контур распределения РЗЭ в сиенитах; 2 - щелочные сиениты; 3 - квариевые монцонитыл; 4 -монцонить

Fig. 5. REE distribution in syenites and monzonites of the Siya-Ushpinsky interfluve. Values are normalized to chondrite according to [40]. 1 - generalized outline of REE distribution in syenites; 2 - alkaline syenites; 3 -quartz monzonites; 4 - monzonites

\section{Интерпретация результатов}

Высокие отношения $\mathrm{Nb} / \mathrm{Ta}$ (от 19,0 до 31,4) и $\mathrm{Zr} / \mathrm{Hf}$ (от 30,4 до 60,6) в сиенитоидах и монцонитах Сия-Ушпинского междуречья свидетельствуют о вовлечении в плавление материала нижней коры [43]. Относительно низкие концентрации $\mathrm{Ni}$ (от 2,3 до 4,1 г/т), $\mathrm{Cr}$ (от 1,0 до 3,2 г/т) и $\mathrm{MgO}$ (от 0,27 до 1,39\%) в сиенитах и монцонитах указывают на то, что они не могли быть продуктом прямого плавления мантийной магмы и результатом фракционирования мафических минералов из эволюционированного расплава $[44,45]$. 
Следовательно, наиболее вероятна их генерация при плавлении пород нижней коры.

Экспериментальные диаграммы, полученные в результате плавления разных типов пород земной коры, позволяют реставрировать источник плавления для магматических пород. На таких диаграммах отчётливо видно, что составы сиенитоидов и монцонитов Сия-Ушпинского междуречья попадают или близко тяготеют к полям плавления амфиболитов и граувакк (рис. 6, $a-8$ ).
На диаграмме $\mathrm{A} / \mathrm{CNK}-\mathrm{SiO}_{2}$ составы сиенитов и монцонитов тяготеют к средним составам сланцев Северной Америки и пост-архейским Австралийским осадочным породам (рис. 6, 2 ).

Следовательно, генерация сиенитов и монцонитов Сия-Ушпинского междуречья происходила по сценарию, в котором основная роль отводится расплавам, сформированным в результате частичного плавления материала нижней утолщённой коры.
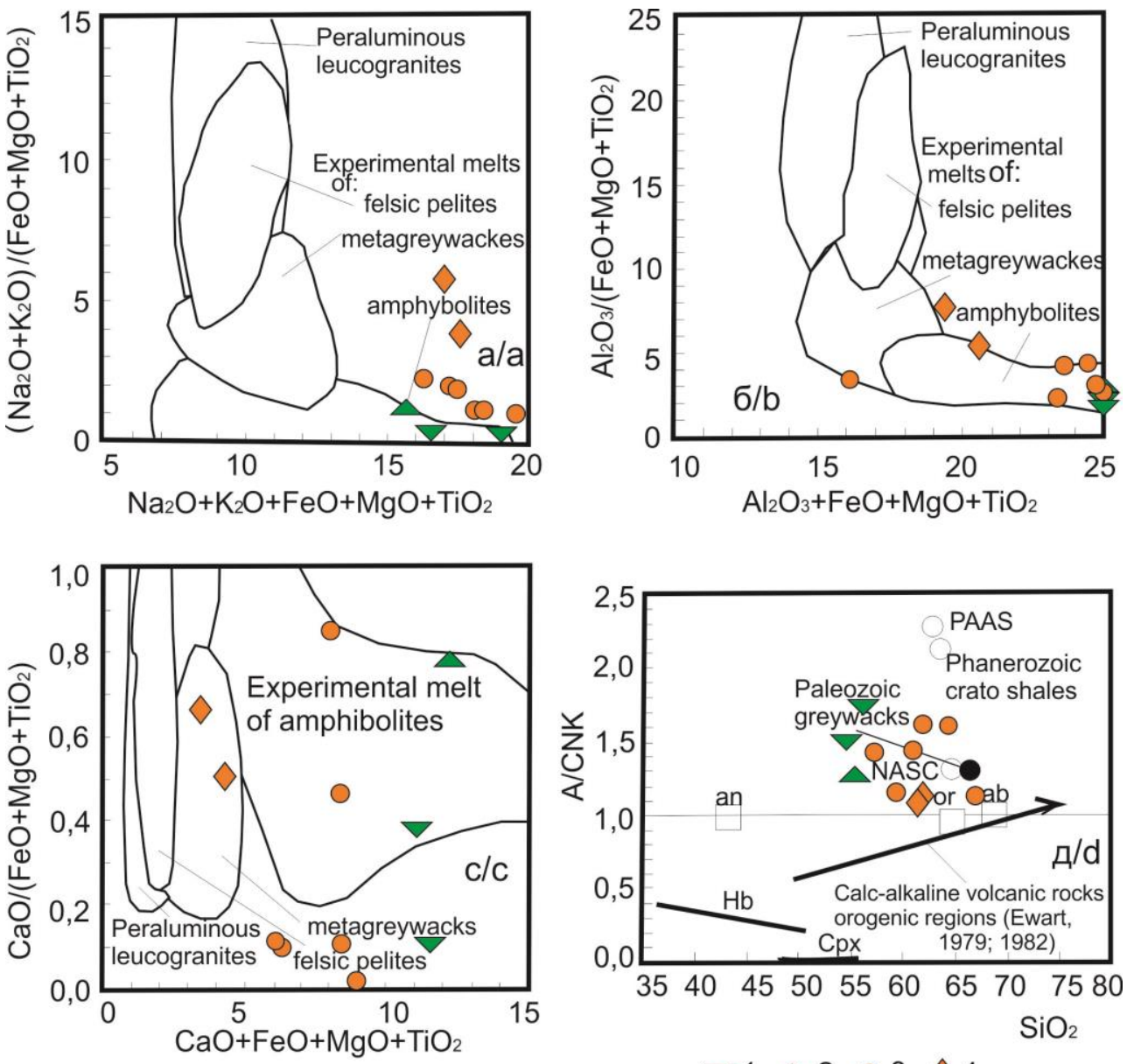

Pис. 6. Монциониты и сиениты Сия-Ушпинского междуречья на экспериментальных диаграммах: а-в) диаграммы состава экспериментальных расплавов из плавления фельзических пелитов (мусковитовых сланцев), метаграувакк и амфиболитов [38]; д) диаграмма $\mathrm{A} / \mathrm{CNK}-\mathrm{SiO}_{2}$ [46, 47]. Тренд известково-щелочного фракционирования вулканических пород орогенных регионов показан по [46, 47]. $\mathrm{A}-\mathrm{Al}_{2} \mathrm{O}_{3}, \mathrm{CNK}-$ сумма $\mathrm{CaO}, \mathrm{Na}_{2} \mathrm{O}, \mathrm{K}_{2} \mathrm{O}$ NASC - сланцы Северной Америки; РAAS - средний состав пост-архейских осадочных пород Австралии. Остальные условные обозначения показаны на рис. 3

Fig. 6. Experimental plots: $a-c$ ) plots of composition of experimental melts from melting felsic pelites (muscovite shales), metagreywack and amphibolite [38] for monzonites and syenites of the Siya-Ushpinsky interfluve; d) plot SiO $\mathrm{S}_{2}-$ A/CNK [46, 47] for monzonites and syenites of the Siya-Ushpinsky interfluve. The trend of calc-alkaline fractionation of volcanic rocks of orogenic regions is presented according to [46, 47]. $\mathrm{A}-\mathrm{Al}_{2} \mathrm{O}_{3}, \mathrm{CNK}-$ sum of $\mathrm{CaO}, \mathrm{Na}_{2} \mathrm{O}, \mathrm{K}_{2} \mathrm{O}$. NASC - composition of the shale of North America; PAAS - average composition of post-Archean sedimentary rocks of Australia. Legend is shown in Fig. 3

Рудоносность сиенитоидов Сия-Ушпинского междуречья проявлена в том, что пространственно с областью распространения сиенитов и монцонитов связаны многочисленные проявления золота, золотоносные россыпи, а также Ульменское золото-медноскарновое месторождение. На последнем наиболее богатое оруденение тяготеет к дайкам сиенитов. Содержания золота в породных типах имеют широкий диапазон величин - от 152 до 255 г/т, а тренд увеличения концентраций металла коррелируется с увеличением значений тетрад-эффекта М-типа в спектре распределения редкоземельных элементов (рис. 7). 


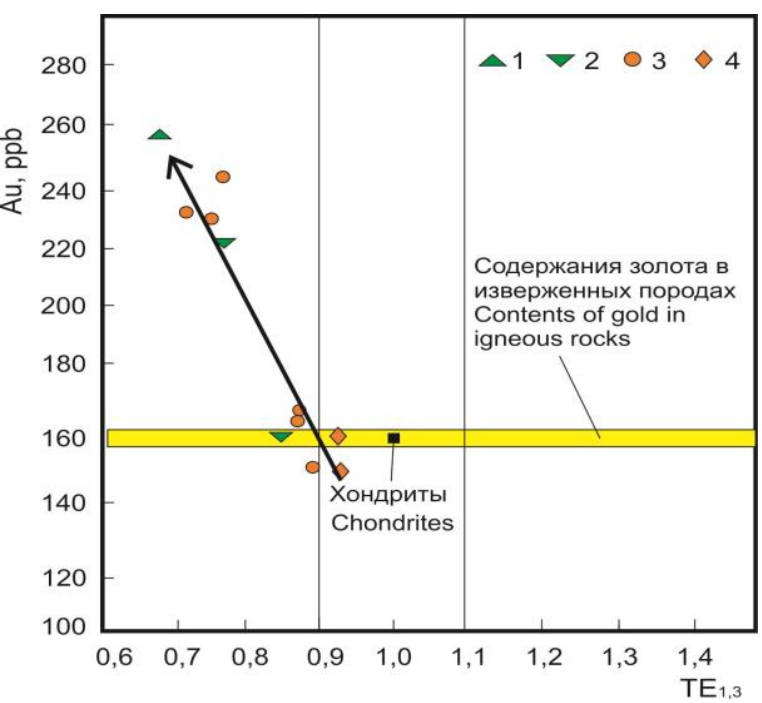

Как известно, проявление тетрад-эффекта фракционирования РЗЭ М-типа в интрузивных породах обусловлено активностью во флюидах таких летучих компонентов, как $\mathrm{CO}_{2}$ и $\mathrm{H}_{2} \mathrm{O}$. Это позволяет предполагать, что перенос золота и других металлов из глубинного очага к местам рудолокализации происходил при участии магматогенных флюидов, обогащённых этими летучими компонентами.

\section{СПИСОК ЛИТЕРАТУРЫ}

1. Jung S., Hauff F., Berndt J. Generation of a potassic to ultrapotassic alkaline complex in a syn-collisional setting through flat subduction: constraints on magma sources and processes (Otjimbingwe alkaline complex, Damara orogen, Namibia) // Gondwana Research. - 2020. - V. 82. - P. 267-287.

2. Coulson I.M., Russell J.K., Dipple G.M. Origins of the Zippa Mountain pluton: a Late Triassic, arc-derived, ultrapotassic magma from the Canadian Cordillera // Canadian Journal of Earth Sciences. - 1999. - V. 36. - № 9. - P. 1415-1434.

3. Petrogenesis of an alkali syenite-granite-rhyolite suite in the Yanshan fold and Thrust Belt, Eastern North China Craton geochronological, geochemical and $\mathrm{Nd}-\mathrm{Sr}-\mathrm{Hf}$ isotopic evidence for lithospheric thinning / J.-H. Yang, F.-Y. Wu, S.A. Wilde, F. Chen, X.-M. Liu, L.-W. Xie // Journal of Petrology. - 2008. V. 49. - № 2. - P. 315-351.

4. Trace elements and $\mathrm{Sr}-\mathrm{Nd}-\mathrm{Pb}$ isotopes of K-rich, shoshonitic, and calc-alkaline magmatism of the Western Mediterranean Region: genesis of ultrapotassic to calc-alkaline magmatic associations in a post-collisional geodynamic setting / S. Conticelli, L. Guarnieri, A. Farinelli, M. Mattei, R. Avanzinelli, G. Bianchini, E. Boari, S. Tommasini, M. Tiepolo, D. Prelević, G. Venturelli // Lithos. 2009. - V. 107. - № 1-2. - P. 68-92.

5. Petrogenesis of silica-saturated and silica-undersaturated syenites in the northern North China Craton related to post-collisional and intraplate extension / J.-H. Yang, J.-F. Sun, M. Zhang, F.-Y. Wu, S.A. Wilde // Chemical Geology. - 2012 - V. 328 - P. 149-167.

6. Alkali-calcic and alkaline post-orogenic (PO) granite magmatism: petrologic constraints and geodynamic settings / B. Bonin, A. Azzouni-Sekkal, F. Bussy, S. Ferrag // Lithos. - 1998. V. 45. - № 1-4. - P. 45-70.

7. Sylvester P.J. Post-collisional alkaline granites // The Journal of Geology. - 1989. - V. 97. - № 3. - P. 261-280.

8. Whalen J.B., Currie K.L., Chappell B.W. A-type granites: geochemical characteristics, discrimination and petrogenesis // Contributions to Mineralogy and Petrology. - 1987. - V. 95. - P. 407-419.

9. Origin of Late Permian syenite and gabbro from the Panxi rift, SW China: the fractionation process of mafic magma in the inner zone of the Emeishan mantle plume / Z. Zhang, J. Qin, S. Lai, X. Long, Y. Ju, X. Wang, Y. Zhu, F. Zhang // Lithos. - 2019. - V. 346-347. Article 105160.
Pис. 7. Сиениты и мониониты Сия-Уипинского междуречья на диаграмме $A$-TE ${ }_{1,3}$ (разработана А.И. Гусевым). Содержания золота в изверженных породах приняты по [48]. Кониентрации золота в хондритах приведены по [49]. Условные обозначения показаны на рис. 3

Fig. 7. Au-TE 1,3 plot for syenites and monzonites of the Siya-Ushpinsky interfluve (created by A.I. Gusev). The gold content in igneous rocks is taken according to [48]. Gold concentration in chondrites is shown according to [49]. Legend is presented in Fig. 3

\section{Заключение}

Сиениты Сия-Ушпинского междуречья имеют абсолютный возраст $501 \pm 4$ млн лет, отвечающий концу среднего кембрия. Химизм монцонитов и сиенитов уверенно диагностирует их принадлежность к шошонитовой серии пород. Их генезис связывается с частичным плавлением утолщённой нижней коры. Породы были насыщены флюидами, в которых важная роль принадлежала $\mathrm{CO}_{2}$ и $\mathrm{H}_{2} \mathrm{O}$. Последние играли важнейшую роль в проявлении тетрад-эффекта фракционирования РЗЭ и переносе золота.

10. Sources and settings of Ediacaran post-collisional syenitemonzonite-diorite shoshonitic magmatism from southernmost Brazil / D.F. Padilha, M.F. Bitencourt, L.V.S. Nardi, L.M. Florisbal, C. Reis, M. Geraldes, B.S. Almeida // Lithos. 2019. - V. 344-345. - P. 482-503.

11. Yan X., Jiang Sh.-Y. Petrogenesis and tectonic implications of Early Cretaceous shoshonitic syenites in the northern Wuyi Mt Range, Southeast China // Journal of Asian Earth Sciences. 2019. - V. 180. - Article 103877

12. The formation of shoshonitic magma and its relationship to porphyry-type mineralisation: the Maronia pluton in NE Greece / A. Schaarschmidt, R. Klemd, M. Regelous, P.C. Voudouris, V. Melfos, K.M. Haase // Lithos. - 2021. - V. 380-381. Article 105911

13. Temporal-spatial analysis of alkaline rocks based on GEOROC / M. Zhang, C. Wang, Q. Zhang, Y. Qin, J. Shen, X. Hu, G. Zhou, S. Li // Applied Geochemistry. - 2021. - V. 124. - Article 104853.

14. $\mathrm{Mg}, \mathrm{Sr}$, and $\mathrm{O}$ isotope geochemistry of syenites from northwest Xinjiang, China: Tracing carbonate recycling during Tethyan oceanic subduction / S. Ke, F.-Z. Teng, S.-G. Li, T. Gao, S.-A. Liu, Y. He, X. Mo // Chemical Geology. - 2016. - V. 437. - P. 109-119.

15. Litvinovsky B.A., Jahn B.M., Eyal M. Mantle-derived sources of syenites from the A-type igneous suites - new approach to the provenance of alkaline silicic magmas // Lithos. - 2015. V. 232. - P. 242-265.

16. Petrogenesis of coeval silica-saturated and silica-undersaturated alkaline rocks: Mineralogical and geochemical evidence from the Saima alkaline complex, NE China / Y.-S. Zhu, J.-H. Yang, J.-F. Sun, J.-H. Zhang, F.-Y. Wu // Journal of Asian Earth Sciences. - 2016. - V. 117. - P. 184-207.

17. Petrogenesis of post-orogenic syenites in the Sulu Orogenic Belt, East China: geochronological, geochemical and $\mathrm{Nd}-\mathrm{Sr}$ isotopic evidence / J.-H. Yang, S.-L. Chung, S.A. Wilde, F.-Y. Wu, M.-F. Chu, C.-H. Lo, H.-R. Fan // Chemical Geology. - 2005. V. 214. - № 1-2. - P. 99-125.

18. Isotopic evidence for the origin of Cenozoic volcanic rocks in the Pinacate volcanic field, northwestern Mexico / D.J. Lynch, T.E. Musselman, J.T. Gutmann, P.J. Patchett // Lithos. - 1993. V. 29. - № 3-4. - P. 295-302.

19. Potassic igneous rocks from the vicinity of epithermal gold mineralization, Lihir Island, Papua New Guinea / D. Müller, 
L. Franz, P.M. Herzig, S. Hunt // Lithos. - 2001. - V. 57. Iss. 2-3. - P. 163-186.

20. The Kirganik alkalic porphyry $\mathrm{Cu}-\mathrm{Au}$ prospect in Kamchatka, Eastern Russia: a shoshonite-related, silica-undersaturated system in a Late Cretaceous island arc setting / S.G. Soloviev, S.G. Kryazhev, V.N. Shapovalenko, G.S. Collins, S.S. Dvurechenskaya, D.S. Bukhanova, A.I. Ezhov, K.I. Voskresensky // Ore Geology Reviews. - 2021. - V. 128. - Article 103893.

21. A metasomatized 180-rich veined lithospheric mantle source for ultrapotassic magmas / W. Fan, N. Jiang, J. Hu, D. Liu, L. Zhao, T. Li // Lithos. - 2021. - V. 382-383. - Article 105964.

22. Dai F.-Q., Zhao Z.-F., Zheng Y.-F. Partial melting of the orogenic lower crust: Geochemical insights from post-collisional alkaline volcanics in the Dabie orogen // Chemical Geology. - 2017. V. 454. - P. $25-43$.

23. Late Triassic melting of a thickened crust in southeastern China: evidence for flat-slab subduction of the Paleo-Pacific plate K.-Y. Zhu, Z.-X. Li, X.-S. Xu, S.A. Wilde // Journal of Asian Earth Sciences. - 2013. - V. 74. - P. 265-279.

24. Huang W.-L., Wyllie P.J. Melting reactions in the system NaAlSi3O8-KAlSi3O8-SiO2 to 35 kilobars, dry and with excess water // The Journal of Geology. - 1975. - V. 83. - № 6. - P. 737-748.

25. Green core clinopyroxenes from Martin Vaz Archipelago PlioPleistocenic alkaline rocks, South Atlantic Ocean, Brazil: a magma mixing and polybaric crystallization record / A.L. de Oliveira, A.C. dos Santos, C.C. Nogueira, T.M. Maia, M.C. Geraldes // Journal of South American Earth Sciences. - 2021. - V. 105. Article 102951.

26. Potassic volcanic rocks and adakitic intrusions in southern Tibet: insights into mantle-crust interaction and mass transfer from Indian plate / D. Liu, Z. Zhao, D.J. DePaolo, D.-C. Zhu, F.-Y. Meng, Q. Shi, Q. Wang // Lithos. - 2017. - V. 268-271. P. $48-64$.

27. Rukhlov A.S., Blinova A.I., Pawlowicz J.G. Geochemistry, mineralogy and petrology of the Eocene potassic magmatism from the Milk River area, southern Alberta, and Sweet Grass Hills, northern Montana // Chemical Geology. - 2013. - V. 353. P. 280-302.

28. Dostal J., Shellnutt J.G., Church B.N. Petrogenesis of an Eocene syenitic intrusion from south-central British Columbia: Evidence for increasing influence of cratonic Laurentia on alkaline magmatism of western North America // Lithos. - 2019. V. 332-333. - P. 67-82.

29. Дворник Г.П., Угрюмов А.Н., Балахонов В.С. Метасоматиты и золотоджаспероидное оруденение в контактовой зоне Аномального щелочного массива с вмещающими карбонатными породами // Известия Уральской государственной горногеологической академии. Серия: Геология и геофизика. 2003. - Вып. 18. - С. 105-109.

30. Гусев А.И. Золотоносные щелочные магматические комплексы // Успехи современного естествознания. - 2012. - № 9. C. $47-52$

31. Yulong Deposit, Eastern Tibet: a high-sulfidation Cu-Au porphyry copper deposit in the Eastern Indo-Asian Collision Zone / Z. Hou, Y. Xie, W. Xu, Y. Li, X. Zhu, Z. Khin, G. Beaudoin, Z. Rui, W. Huang, C. Luobu // International Geology Review. - 2007. V. 49 - Iss. 3 - P. 235-258.

32. Zircon indicators of fluid sources and ore genesis in a multi-stage hydrothermal system: the Dongping Au deposit in North China / H. Li, J.-W. Li, T.J. Algeo, J.-H. Wu, M. Cisse // Lithos. - 2018. V. 314-315. - P. 463-478

33. Bao Z., Li C., Zhao Z. Metallogeny of the syenite-related Dongping gold deposit in the northern part of the North China Craton: a review and synthesis // Ore Geology Reviews. - 2016. V. 73. - P. 2. - P. 198-210
34. Корреляция магматических и метаморфических комплексов западной части Алтае-Саянской складчатой области / С.П. Шокальский, Г.А. Бабин, А.Г. Владимиров, Н.И. Гусев, В.Н. Токарев, В.А. Зыбин, В.С. Дубский, О.В. Мурзин, В.А. Кривчиков, Н.Н. Крук, С.Н. Руднев, Г.С. Федосеев, А.В. Титов, В.П. Сергеев, Н.Н. Лихачёв, А.Н. Мамлин, Е.И. Котельников, С.А. Кузнецов, Л.Л. Зейферт, В.Д. Яшин, Ю.С. Носков, А.Н. Уваров, С.И. Федак, А.И. Гусев, С.А. Выставной. - Новосибирск: Изд-во СО РАН, филиал «Гео», 2000. $-187 \mathrm{c}$.

35. Гусев А.И., Табакаева Е.М. Магматизм и металлогения Салаира. - Бийск: АГГПУ им. В.М. Шукшина, 2017. - 182 с.

36. Middlemost E.A.K. Naming materials in the magma/igneous rock system // Earth-Science Reviews. - 1994. - V. 37. - № 3-4. P. 215-224.

37. Wright J.B. A simple alkalinity ratio and its application to questions of non-orogenic granite genesis // Geological Magazine. - 1969. - V. 106. - № 4. - P. 370-384.

38. Patiño Douce A.E. What do experiments tell us about the relative contributions of crust and mantle to the origin of granitic magmas? // Geological Society. Special Publications. - 1999. - V. 168. P. 55-75.

39. Irber $\mathrm{W}$. The lanthanide tetrad effect and its correlation with $\mathrm{K} / \mathrm{Rb}$, $\mathrm{Eu} / \mathrm{Eu} *, \mathrm{Sr} / \mathrm{Eu}, \mathrm{Y} / \mathrm{Ho}$, and $\mathrm{Zr} / \mathrm{Hf}$ of evolving peraluminous granite suites // Geochimica et Cosmochimica Acta. - 1999. - V. 63. № 3-4. - P. 489-508.

40. Anders E., Grevesse N. Abundances of the elements: meteoritic and solar // Geochimica et Cosmochimica Acta. - 1989. - V. 53. № 1. - P. 197-214.

41. Гусев А.И., Гусев Н.И., Одинцев А.В. Геохимия, петрология и генезис ульменского сиенит-пироксенит-габбрового комплекса Северного Алтая // Природные ресурсы Горного Алтая: геология, геофизика, экология, минеральные, водные и лесные ресурсы Алтая. - 2019. - № 1-2. - С. 29-40.

42. Peccerillo A., Taylor S.R. Rare earth elements in East Carpathian volcanic rocks // Earth and Planetary Science Letters. - 1976. V. 32. - № 2. - P. 121-126.

43. Rudnick R.L., Gao S. Composition of the continental crust // Treatise on Geochemistry. V. 3: the Crust / Ed. by R. Rudnick. Amsterdam: Elsevier, 2003. - P. 1-64.

44. Frost C.D., Frost B.R. Reduced rapakivi-type granites: the tholeiite connection // Geology. - 1997. - V. 25. - № 7. - P. 647-650.

45. Trace elements and Sr-Nd isotopic geochemistry and genesis of Jijie alkaline-ultramafic rocks, southern part of Panxi rift / Z. Zhao, L. Qi, Z.L. Huang, Z.F. Yan, C. Xu // Acta Petrologica Sinica. 2012. - № 6. - P. 1915-1927.

46. Ewart A. A review of the mineralogy and chemistry of TertiaryRecent dacitic, latitic, rhyolitic, and related salic volcanic rocks // Trondjemites, Dacites, and Related Rocks. - Amsterdam: Elsevier, 1979. - P. 13-121.

47. Ewart A. The mineralogy and petrology of Tertiary - recent orogenic volcanic rocks: with special reference to the andesiticbasaltic compositional range // Andesites: Orogenic Andesites and Related Rocks. - Chichester; New York; Brisbane; Toronto; Singapore: John Wiley and Sons, 1982. - P. 25-95.

48. Виноградов А.П. Среднее содержание химических элементов в горных породах // Геохимия. - 1962. - № 7. - С. 555-571.

49. Wasson J.T., Kallemeyn G.W. Compositions of chondrites // Philosophical Transactions of the Royal Society A: Mathematical, Physical and Engineering Sciences. - 1988. - V. 325. - № 1587. P. 535-544

Поступила 06.01.2021 г.

\section{Информация об авторах}

Гусев А.И., доктор геолого-минералогических наук, профессор кафедры естественно-научных дисциплин Алтайского государственного гуманитарно-педагогического университета им. В.М. Шукшина.

Taбакаева E.M., кандидат геолого-минералогических наук, доцент кафедры экономической географии и картографии Алтайского государственного университета. 
UDC 553.3/4:553.2:550.4

\title{
SYENITES AND MONZONITES IN THE SIYA-USHPINSKY INTERFLUVE OF GORNY ALTAI: ABSOLUTE AGE, GEOCHEMISTRY AND PETROLOGY
}

\author{
Anatoly I. Gusev 1 , \\ anzerg@mail.ru

\section{Evgeniya M. Tabakaeva²,} \\ tabakaevaem@mail.ru \\ 1 Shukshin Altai State Humanities Pedagogical University, \\ 53, Vladimir Korolenko street, Biysk, 659333, Russia. \\ 2 Altai State University, \\ 61, Lenin avenue, Barnaul, 656049, Russia.
}

The relevance of the research is caused by the need to clarify the absolute age and to study the features of petrology and geochemistry of moderately alkaline rocks - syenites and monzonites of the Siya-Ushpinsky interfluve in the northeastern Altai mountains (Russia) - in order to determine the formation patterns of the associated gold mineralization. The problem of the origin of alkaline igneous rocks is still interesting for scientists in many countries due to the fact that these are the rocks used to confirm the mantle-crustal interaction and to determine the nature of the evolution of the continental crust. Today, there is still no single position on their origin.

The aims of the research are to clarify the absolute age of alkaline syenites of the Ulmen ore field and to study the petrological and geochemical features of syenitoids and monzonites of the Siya-Ushpinsky interfluve using a complex of petrological diagrams which help to reveal the physicochemical features of petrogenesis.

The main objects of the study were syenitoids and monzonites of the UImen pyroxenite-syenite-monzonite-gabbro complex of the Middle Cambrian, located in the Siya-Ushpinsky interfluve. This territory is located within the anomalous tectonic block formed at the junction of the Gorno-Altai, Gorno-Shor and Salair structures. Among the minerals, the objects of study are zircons from alkaline syenites of the western section of the Ulmen ore field.

Methods. The absolute age of the rocks was determined by the U-Pb secondary ion mass spectrometry method using a SHRIMP-II ion microprobe on zircon in the Laboratory of the Russian Geological Research Institute (Saint-Petersburg). Geochemical data were interpreted using a set of petrological diagrams. The tetrad effect of fractionation of REE (TE 1.3$)$ was calculated by the method of $V$. Irber.

Results. Syenites in the Siya-Ushpinsky interfluve have the absolute age of $501 \pm 4 \mathrm{Ma}$, which corresponds to the end of the Middle Cambrian. Data on the composition of syenites and monzonites of the Bolshoi Lichim, Ushpa, Ulmeni, Upper Karakan, Salazan areas within the Siya-Ushpinsky interfluve were obtained. The authors established the sequence of formation of rocks with the separation of three phases: phase 1 - monzonite, phase 2 - alkaline syenite, phase 3 - syenite. Monzonites and syenites belong to the rocks of the intermediate composition of the moderately alkaline series. In addition, the composition of the monzonites and syenites studied by us corresponds to the shoshonite series of rocks. High ratios of $\mathrm{Nb} / \mathrm{Ta}$ (from 19,0 to 31,4) and $\mathrm{Zr} / \mathrm{Hf}$ (from 30,4 to 60,6) in syenitoids and monzonites of the SiyaUshpinsky interfluve indicate the involvement of lower crust material in melting. Relatively low concentrations of $\mathrm{Ni}$ (from 2,3 to 4,1 ppm), $\mathrm{Cr}$ (from 1,0 to 3,2 ppm) and $\mathrm{MgO}$ (from 0,27 to 1,39 \%) in syenites and monzonites indicate that they could not be the product of direct melting of mantle magma and the result of fractionation of mafic minerals from the evolved melt. Consequently, in the generation of syenites and monzonites of the Siya-Ushpinsky interfluve, the main role was played by melts formed as a result of partial melting of the lower thickened crust. In the experimental diagrams that allow the restoration of the source of melting for igneous rocks, the compositions of syenitoids and monzonites of the Siya-Ushpinsky interfluve fall or close to the melting fields of amphibolites and graywackes. In the studied rocks, the tetrad effect of fractionation of M-type REEs was revealed, which indicates their saturation with fluids, among which such volatile components as $\mathrm{CO}_{2}$ and $\mathrm{H}_{2} \mathrm{O}$, played an important role. The latter were of key importance for gold transfer. The author's diagram $A u-T E_{1,3}$ shows the trend of increase in gold concentrations with the growth of the tetrad effect of fractionation of M-type REEs. Spatially, the area of distribution of syenites and monzonites is associated with numerous manifestations of gold, gold-bearing placers, as well as the UImen gold-copper-skarn deposit. In the latter, the richest mineralization tends to to the syenite dikes.

\section{Key words:}

Alkaline magmatism, syenites, monzonites, petrology, zircon, tetrad effect of fractionation of rare earth elements, gold, Gorny Altai.

\section{REFERENCES}

1. Jung S., Hauff F., Berndt J. Generation of a potassic to ultrapotassic alkaline complex in a syn-collisional setting through flat subduction: Constraints on magma sources and processes (Otjimbingwe alkaline complex, Damara orogen, Namibia). Gondwana Research, 2020, vol. 82, pp. 267-287. DOI: 10.1016/j.gr.2020.01.004

2. Coulson I.M., Russell J.K., Dipple G.M. Origins of the Zippa Mountain pluton: a Late Triassic, arc-derived, ultrapotassic magma from the Canadian Cordillera. Canadian Journal of Earth Sciences, 1999, vol. 36, no. 9, pp. 1415-1434. DOI: 10.1139/e99-045

3. Yang J.-H., Wu F.-Y., Wilde S.A., Chen F., Liu X.-M., Xie L.-W. Petrogenesis of an Alkali Syenite-Granite-Rhyolite Suite in the
Yanshan Fold and Thrust Belt, Eastern North China Craton: Geochronological, Geochemical and Nd-Sr-Hf Isotopic Evidence for Lithospheric Thinning. Journal of Petrology, 2008, vol. 49, no. 2, pp. 315-351. DOI: 10.1093/petrology/egm083

4. Conticelli S., Guarnieri L., Farinelli A., Mattei M., Avanzinelli R., Bianchini G., Boari E., Tommasini S., Tiepolo M., Prelević D., Venturelli G. Trace elements and $\mathrm{Sr}-\mathrm{Nd}-\mathrm{Pb}$ isotopes of K-rich, shoshonitic, and calc-alkaline magmatism of the Western Mediterranean Region: Genesis of ultrapotassic to calc-alkaline magmatic associations in a post-collisional geodynamic setting. Lithos, 2009, vol. 107, no. 1-2, pp. 68-92. DOI: 10.1016/j.lithos.2008.07.016

5. Yang J.-H., Sun J.-F., Zhang M., Wu F.-Y., Wilde S.A. Petrogenesis of silica-saturated and silica-undersaturated syenites in the northern North China Craton related to post-collisional and in- 
traplate extension. Chemical Geology, 2012, vol. 328, pp. 149-167. DOI: 10.1016/j.chemgeo.2011.09.011

6. Bonin B., Azzouni-Sekkal A., Bussy F., Ferrag S. Alkali-calcic and alkaline post-orogenic (PO) granite magmatism: petrologic constraints and geodynamic settings. Lithos, 1998, vol. 45, no. 1-4 pp. 45-70. DOI: 10.1016/S0024-4937(98)00025-5

7. Sylvester P.J. Post-collisional alkaline granites. The Journal of Geology, 1989, vol. 97, no. 3, pp. 261-280. DOI: 10.1086/629302

8. Whalen J.B., Currie K.L., Chappell B.W. A-type granites: geochemical characteristics, discrimination and petrogenesis. Contributions to Mineralogy and Petrology, 1987, vol. 95, pp. 407-419. DOI: $10.1007 / \mathrm{BF} 00402202$

9. Zhang Z., Qin J., Lai S., Long X., Ju Y., Wang X., Zhu Y., Zhang F. Origin of Late Permian syenite and gabbro from the Panxi rift, SW China: the fractionation process of mafic magma in the inner zone of the Emeishan mantle plume. Lithos, 2019, vol. 346-347, Article 105160. DOI: 10.1016/j.lithos.2019.105160

10. Padilha D.F., Bitencourt M.F., Nardi L.V.S., Florisbal L.M., Reis C Geraldes M., Almeida B.S. Sources and settings of Ediacaran postcollisional syenite-monzonite-diorite shoshonitic magmatism from southernmost Brazil. Lithos, 2019, vol. 344-345, pp. 482-503. DOI: 10.1016/j.lithos.2019.06.004

11. Yan X., Jiang Sh.-Y. Petrogenesis and tectonic implications of Early Cretaceous shoshonitic syenites in the northern Wuyi Mt Range, Southeast China. Journal of Asian Earth Sciences, 2019, vol. 180, article 103877. DOI: 10.1016/j.jseaes.2019.103877

12. Schaarschmidt A., Klemd R., Regelous M., Voudouris P.C., Melfos V., Haase K.M. The formation of shoshonitic magma and its relationship to porphyry-type mineralisation: the Maronia pluton in NE Greece. Lithos, 2021, vol. 380-381, Article 105911. DOI: 10.1016/j.lithos.2020.105911

13. Zhang M., Wang C., Zhang Q., Qin Y., Shen J., Hu X., Zhou G., Li S. Temporal-spatial analysis of alkaline rocks based on GEOROC Applied Geochemistry, 2021, vol. 124, Article 104853. DOI: 10.1016/j.apgeochem.2020.104853

14. Ke S., Teng F.-Z., Li S.-G., Gao T., Liu S.-A., He Y., Mo X. Mg, $\mathrm{Sr}$, and $\mathrm{O}$ isotope geochemistry of syenites from northwest Xinjiang, China: tracing carbonate recycling during Tethyan oceanic subduction. Chemical Geology, 2016, vol. 437, pp. 109-119. DOI: 10.1016/j.chemgeo.2016.05.002

15. Litvinovsky B.A., Jahn B.M., Eyal M. Mantle-derived sources of syenites from the A-type igneous suites - new approach to the provenance of alkaline silicic magmas. Lithos, 2015, vol. 232, pp. 242-265. DOI: 10.1016/j.lithos.2015.06.008

16. Zhu Y.-S., Yang J.-H., Sun J.-F., Zhang J.-H., Wu F.-Y. Petrogenesis of coeval silica-saturated and silica-undersaturated alkaline rocks: mineralogical and geochemical evidence from the Saima alkaline complex, NE China. Journal of Asian Earth Sciences, 2016, vol. 117, pp. 184-207. DOI: 10.1016/j.jseaes.2015.12.014

17. Yang J.-H., Chung S.-L., Wilde S.A., Wu F.-Y., Chu M.-F., Lo C.-H., Fan H.-R. Petrogenesis of post-orogenic syenites in the Sulu Orogenic Belt, East China: geochronological, geochemical and $\mathrm{Nd}-\mathrm{Sr}$ isotopic evidence. Chemical Geology, 2005, vol. 214, no. 1-2, pp. 99-125. DOI: 10.1016/j.chemgeo.2004.08.053

18. Lynch D.J., Musselman T.E., Gutmann J.T., Patchett P.J. Isotopic evidence for the origin of Cenozoic volcanic rocks in the Pinacate volcanic field, northwestern Mexico. Lithos, 1993, vol. 29, no. 3-4 pp. 295-302. DOI: 10.1016/0024-4937(93)90023-6

19. Müller D., Franz L., Herzig P.M., Hunt S. Potassic igneous rocks from the vicinity of epithermal gold mineralization, Lihir Island, Papua New Guinea. Lithos, 2001, vol. 57, no. 2-3, pp. 163-186. DOI: 10.1016/S0024-4937(01)00035-4

20. Soloviev S.G., Kryazhev S.G., Shapovalenko V.N., Collins G.S., Dvurechenskaya S.S., Bukhanova D.S., Ezhov A.I., Voskresensky K.I The Kirganik alkalic porphyry Cu-Au prospect in Kamchatka, Eastern Russia: a shoshonite-related, silica-undersaturated system in a Late Cretaceous island arc setting. Ore Geology Reviews, 2021, vol. 128, Article 103893. DOI: 10.1016/j.oregeorev.2020.103893

21. Fan W., Jiang N., Hu J., Liu D., Zhao L., Li T. A metasomatized ${ }^{18} \mathrm{O}$-rich veined lithospheric mantle source for ultrapotassic magmas. Lithos, 2021, vol. 382-383, Article 105964. DOI: 10.1016/j.lithos.2020.105964

22. Dai F.-Q., Zhao Z.-F., Zheng Y.-F. Partial melting of the orogenic lower crust: Geochemical insights from post-collisional alkaline volcanics in the Dabie orogen. Chemical Geology, 2017, vol. 454, pp. 25-43. DOI: 10.1016/j.chemgeo.2017.02.022

23. Zhu K.-Y., Li Z.-X., Xu X.-S., Wilde S.A. Late Triassic melting of a thickened crust in southeastern China: evidence for flat-slab subduction of the Paleo-Pacific plate. Journal of Asian Earth Sciences, 2013, vol. 74, pp. 265-279. DOI: 10.1016/j.jseaes.2013.01.010

24. Huang W.-L., Wyllie P.J. Melting reactions in the system $\mathrm{NaAlSi}_{3} \mathrm{O}_{8}-\mathrm{KAlSi}_{3} \mathrm{O}_{8}-\mathrm{SiO}_{2}$ to 35 kilobars, dry and with excess water. The Journal of Geology, 1975, vol. 83, no. 6, pp. 737-748. DOI: $10.1086 / 628165$

25. Oliveira de A.L., Santos dos A.C., Nogueira C.C., Maia T.M., Geraldes M.C. Green core clinopyroxenes from Martin Vaz Archipelago Plio-Pleistocenic alkaline rocks, South Atlantic Ocean, Brazil: A magma mixing and polybaric crystallization record. Journal of South American Earth Sciences, 2021, vol. 105, Article 102951. DOI: 10.1016/j.jsames.2020.102951

26. Liu D., Zhao Z., DePaolo D.J., Zhu D.-C., Meng F.-Y., Shi Q., Wang Q. Potassic volcanic rocks and adakitic intrusions in southern Tibet: Insights into mantle-crust interaction and mass transfer from Indian plate. Lithos, 2017, vol. 268-271, pp. 48-64. DOI: 10.1016/j.lithos.2016.10.034

27. Rukhlov A.S., Blinova A.I., Pawlowicz J.G. Geochemistry, mineralogy and petrology of the Eocene potassic magmatism from the Milk River area, southern Alberta, and Sweet Grass Hills, northern Montana. Chemical Geology, 2013, vol. 353, pp. 280-302. DOI: 10.1016/j.chemgeo.2012.10.024

28. Dostal J., Shellnutt J.G., Church B.N. Petrogenesis of an Eocene syenitic intrusion from south-central British Columbia: Evidence for increasing influence of cratonic Laurentia on alkaline magmatism of western North America. Lithos, 2019, vol. 332-333, pp. 67-82. DOI: 10.1016/j.lithos.2019.01.023

29. Dvornik G.P., Ugryumov A.N., Balahonov V.S. Metasomatity i zolotodzhasperoidnoe orudenenie $\mathrm{v}$ kontaktovoy zone Anomalnogo shchelochnogo massiva $\mathrm{s}$ vmeshchayushchimi karbonatnymi porodami [Metasomatites and gold-jasperoid mineralization in the contact zone of the Anomalous alkaline massif with host carbonate rocks]. Izvestiâ Uralskogo gosudarstvennogo gornogo universiteta. Seriya: Geologiya i geofizika, 2003, no. 18, pp. 105-109.

30. Gusev A.I. Gold-bearing alkaline igneous complexes. Advances in current natural sciences, 2012, no. 9, pp. 47-52. In Rus.

31. Hou Z., Xie Y., Xu W., Li Y., Zhu X., Khin Z., Beaudoin G., Rui Z., Huang W., Luobu C. Yulong Deposit, Eastern Tibet: A HighSulfidation $\mathrm{Cu}$-Au Porphyry Copper Deposit in the Eastern IndoAsian Collision Zone. International Geology Review, 2007, vol. 49, no. 3, pp. 235-258. DOI: 10.2747/0020-6814.49.3.235

32. Li H., Li J.-W., Algeo T.J., Wu J.-H., Cisse M. Zircon indicators of fluid sources and ore genesis in a multi-stage hydrothermal system: The Dongping Au deposit in North China. Lithos, 2018, vol. 314-315, pp. 463-478. DOI: 10.1016/j.lithos.2018.06.025

33. Bao Z., Li C., Zhao Z. Metallogeny of the syenite-related Dongping gold deposit in the northern part of the North China Craton: a review and synthesis. Ore Geology Reviews, 2016, vol. 73, P. 2, pp. 198-210. DOI: 10.1016/j.oregeorev.2015.04.002

34. Shokalskii S.P., Babin G.A., Vladimirov A.G., Gusev N.I., Tokarev V.N., Zybin V.A., Dubskiy V.S., Murzin O.V., Krivchikov V.A., Kruk N.N., Rudnev S.N., Fedoseev G.S., Titov A.V., Sergeev V.P., Likhachev N.N., Mamlin A.N., Kotelnikov E.I., Kuznetsov S.A., Zeyfert L.L., Yashin V.D., Noskov Yu.S., Uvarov A.N., Fedak S.I., Gusev A.I., Vystavnoy S.A. Korrelyatsiya magmaticheskikh i metamorficheskikh kompleksov zapadnoy chasti Altae-Sayanskoy skladchatoy oblasti [Correlation of magmatic and metamorphic complexes in the western part of the Altai-Sayan fold area]. Novosibirsk, SO RAN Publ., 2000. 187 p.

35. Gusev A.I., Tabakaeva E.M. Magmatizm i metallogeniya Salaira [Magmatism and metallogeny of Salair]. Biysk, AGGPU im. V.M. Shukshina, 2017. 182 p.

36. Middlemost E.A.K. Naming materials in the magma/igneous rock system. Earth-Science Reviews, 1994, vol. 37, no. 3-4, pp. 215-224. DOI: $10.1016 / 0012-8252(94) 90029-9$

37. Wright J.B. A simple alkalinity ratio and its application to questions of non-orogenic granite genesis. Geological Magazine, 1969, vol. 106, no. 4, pp. 370-384. DOI: 10.1017/S0016756800058222

38. Patiño Douce A.E. What do experiments tell us about the relative contributions of crust and mantle to the origin of granitic magmas? 
Geological Society. Special Publications, 1999, vol. 168, pp. 55-75. DOI: 10.1144/GSL.SP.1999.168.01.05

39. Irber $\mathrm{W}$. The lanthanide tetrad effect and its correlation with $\mathrm{K} / \mathrm{Rb}$, $\mathrm{Eu} / \mathrm{Eu}{ }^{*}, \mathrm{Sr} / \mathrm{Eu}, \mathrm{Y} / \mathrm{Ho}$, and $\mathrm{Zr} / \mathrm{Hf}$ of evolving peraluminous granite suites. Geochimica et Cosmochimica Acta, 1999, vol. 63, no. 3-4, pp. 489-508. DOI: 10.1016/S0016-7037(99)00027-7

40. Anders E., Grevesse N. Abundances of the elements: meteoritic and solar. Geochimica et Cosmochimica Acta, 1989, vol. 53, no. 1, pp. 197-214. DOI: 10.1016/0016-7037(89)90286-X

41. Gusev A.I., Gusev N.I., Odintsev A.V. Geokhimiya, petrologiya i genezis ulmenskogo sienit-piroksenit-gabbrovogo kompleksa Severnogo Altaya [Geochemistry, petrology, and genesis of the Ulmen syenite-pyroxenite-gabbro complex of Northern Altai]. Prirodnye resursy Gornogo Altaya: geologiya, geofizika, ekologiya, mineralnye, vodnye $i$ lesnye resursy Altaya, 2019, no. 1-2, pp. 29-40.

42. Peccerillo A., Taylor S.R. Rare earth elements in East Carpathian volcanic rocks. Earth and Planetary Science Letters, 1976, vol. 32, no. 2, pp. 121-126. DOI: $10.1016 / 0012-821$ X(76)90050-9

43. Rudnick R.L., Gao S. Composition of the continental crust. In R. Rudnick (Ed.), Treatise on Geochemistry, Vol. 3: the Crust. Amsterdam, Elsevier, 2003. pp. 1-64. DOI: 10.1016/B0-08-0437516/03016-4

44. Frost C.D., Frost B.R. Reduced rapakivi-type granites: the tholeiite connection. Geology, 1997, vol. 25, no. 7, pp. 647-650. DOI: 10.1130/0091-7613(1997)025<0647:RRTGTT>2.3.CO;2
45. Zhao Z., Qi L., Huang Z.L., Yan Z.F., Xu C. Trace elements and Sr-Nd isotopic geochemistry and genesis of Jijie alkalineultramafic rocks, southern part of Panxi rift. Acta Petrologica Sinica, 2012, no. 6, pp. 1915-1927.

46. Ewart A. A review of the mineralogy and chemistry of TertiaryRecent dacitic, latitic, rhyolitic, and related salic volcanic rocks. Trondjemites, Dacites, and Related Rocks. Ed. by F. Barker. Amsterdam, Elsevier, 1979. pp. 13-121.

47. Ewart A. The mineralogy and petrology of Tertiary - recent orogenic volcanic rocks: with special reference to the andesiticbasaltic compositional range. Andesites: Orogenic Andesites and Related Rocks. Ed. by R.S. Thorpe. Chichester, New York, Brisbane, Toronto, Singapore, John Wiley and Sons, 1982. pp. 25-95.

48. Vinogradov A.P. Srednee soderzhanie khimicheskikh elementov v gornykh porodakh [Average content of chemical elements in rocks]. Geochemistry International, 1962, no. 7, pp. 555-571.

49. Wasson J.T., Kallemeyn G.W. Compositions of chondrites. Philosophical Transactions of the Royal Society A: Mathematical, Physical and Engineering Sciences, 1988, vol. 325, no. 1587, pp. 535544. DOI: 10.1098/rsta.1988.0066

Received: 6 January 2021.

\section{Information about the authors}

Anatoly I. Gusev, Dr. Sc., professor, Shukshin Altai State Humanities Pedagogical University.

Evgeniya M. Tabakaeva, Cand. Sc., associate professor, Altai State University. 